\title{
Enhancement of antibacterial property of titanium by two-step micro arc oxidation treatment
}

\author{
Masaya SHIMABUKURO ${ }^{1,2}$, Harumi TSUTSUMI ${ }^{3}$, Yusuke TSUTSUMI ${ }^{4}$, Tomoyo MANAKA², Peng CHEN ${ }^{3}$, \\ Maki ASHIDA ${ }^{3}$, Kunio ISHIKAWA ${ }^{1}$, Hideki KATAYAMA ${ }^{4}$ and Takao HANAWA ${ }^{3}$ \\ ${ }^{1}$ Department of Biomaterials, Faculty of Dental Science, Kyushu University, 3-1-1 Maidashi, Higashi-ku, Fukuoka 812-8582, Japan \\ ${ }^{2}$ Graduate School of Medical and Dental Sciences, Tokyo Medical and Dental University (TMDU), 1-5-45 Yushima, Bunkyo-ku, Tokyo 113-8510, \\ Japan \\ ${ }^{3}$ Institute of Biomaterials and Bioengineering, Tokyo Medical and Dental University (TMDU), 2-3-10 Kanda-Surugadai, Chiyoda-ku, Tokyo 101-0062, \\ Japan \\ ${ }^{4}$ Research Center for Structural Materials, National Institute for Materials Science (NIMS), 1-2-1 Sengen, Tsukuba, Ibaraki 305-0047, Japan \\ Corresponding authors, Yusuke TSUTSUMI; E-mail: TSUTSUMI.Yusuke@nims.go.jp, Harumi TSUTSUMI; E-mail: htsutsumi.met@tmd.ac.jp
}

A customized micro arc oxidation (MAO) treatment technique was developed to obtain desirable antibacterial properties on titanium surfaces. The two-step MAO treatment was applied to fabricate a specimen containing both Ag and $\mathrm{Zn}$ in its surface oxide layer. Surface analyses and metal-ion release tests were performed to evaluate the presence of $\mathrm{Ag}$ and $\mathrm{Zn}$ and the ion release behavior for simulating practical usage, respectively. Additionally, the antibacterial properties of the specimens were also evaluated using gram-negative facultative anaerobic bacteria. The MAO-treated specimens containing both $\mathrm{Ag}$ and $\mathrm{Zn}$ showed excellent antibacterial properties against Escherichia coli, and the properties were sustained even after 28 days of immersion in physiological saline to simulate the living environment.

Keywords: Micro arc oxidation, Antibacterial property, Silver, Zinc, Escherichia coli

\section{INTRODUCTION}

Titanium (Ti) and its alloys are widely used in dental and medical devices owing to their excellent mechanical properties and biocompatibility. These implant devices have been associated with accelerated and strong adhesion between the implant surface and the surrounding bone to achieve a shorter healing period and immediate loading ${ }^{1-4}$. However, in recent years, biofilm formation due to bacterial adhesion, and the subsequent colonization on biomaterials, have been recognized as major causes of failure in dental and orthopedic implant surgeries ${ }^{5-9}$. Once a biofilm is formed and firmly adhered to the implanted material, bacterial secretion plays a pestiferous role as a barrier against the defense mechanism of the host. Thus, pathogens are difficult to eliminate upon formation of a biofilm on a device implanted in a living body. In serious cases, there is no way to remove the contaminated devices from the patient and to prevent subsequent undesirable biological reactions such as infections. The easiest strategy to prevent the formation of biofilms on metallic devices is polishing because a roughened surface is known to enhance bacterial adhesion. It has been reported that the increase in the surface area and the formation of pockets enhanced the presence of bacteria ${ }^{10,11)}$. On the other hand, for dental implants and orthodontic fixators used in contact with bone, a roughened surface is always preferred to ensure hard-tissue compatibility. Therefore, another appropriate way to prevent biofilm formation is the application of antibacterial agents.

Silver $(\mathrm{Ag})$ ions are known as one of the most effective agents because they exhibit superior antibacterial properties ${ }^{12-15)}$. Surface modification enables the formation of a biofunctional layer supporting $\mathrm{Ag}$ because a source of Ag ions can overcome the problems caused by biofilm formation on metallic biomaterials. In addition to the efficacy of Ag against bacteria, Zn has also been attracting attention as an antibacterial element owing to its antibacterial activity ${ }^{16-22)}$.

Micro arc oxidation (MAO) is a conventional wetprocess surface treatment, based on electrochemical reactions in a specific electrolyte under high voltage. The MAO treatment has already been utilized as a surface treatment in dental implants to enable immediate loading after surgeries ${ }^{23-26)}$. MAO can incorporate calcium (Ca) and phosphorus $(\mathrm{P})$ into the resulting oxide layer ${ }^{27,28)}$. For the treatment, the mentioned elements were originally present in the electrolyte in their ionic states. In other words, incorporation of the selected element into the oxide layer formed by MAO treatment is possible only when the element is dissolved in the electrolyte. This technique can be utilized for incorporating the desired elements into the resulting oxide layer.

Therefore, our study focused on incorporating antibacterial elements into a Ti surface to develop novel antibacterial implants without any harmful effects on osteogenic cells by MAO treatment. We have reported that $\mathrm{Ag}, \mathrm{Cu}$, and $\mathrm{Zn}$ were effective in inhibiting the proliferation of Escherichia coli (E. coli) and/or Staphylococcus aureus (S. aureus) ${ }^{29-32}$. In addition, the inhibition mechanisms and their efficacy were found to differ: Ag showed a strong antibacterial effect, especially during the initial period, $\mathrm{Cu}$ showed specific effectiveness 
Table 1 Features of antibacterial properties incorporated into Ti oxide layers by MAO treatment against $E$. coli and $S$. aureus

\begin{tabular}{ccclc}
\hline \multirow{2}{*}{ Element } & \multicolumn{2}{c}{ Antibacterial effect } & \\
\cline { 2 - 4 } & $\begin{array}{c}\text { Fresh: As- } \\
\text { prepared }\end{array}$ & $\begin{array}{c}\text { Aged: After immersion in } \\
\text { physiological saline for 28 days }\end{array}$ & Remarks \\
\hline $\mathrm{Ag}$ & Strong & Moderate & Release killing by Ag ions & Ref. \\
$\mathrm{Cu}$ & Moderate & Moderate & $\begin{array}{l}\text { Contact killing by Cu/Cu oxides } \\
\text { Release killing by Cu ions } \\
\text { (Induced by bacterial attachment) }\end{array}$ \\
$\mathrm{Zn}$ & Weak & Moderate & $\begin{array}{l}\text { Contact killing by Zn oxides } \\
\text { (Matured from initial Zn products) }\end{array}$ \\
\hline
\end{tabular}

on $S$. aureus, and Zn showed a heightened antibacterial effect over time. The features of antibacterial elements are summarized in Table 1. From the viewpoint of solving the late-onset infection problem ${ }^{33-35)}$ that occurs around three to eight weeks after surgery, long-term antibacterial activity of the implant material is strongly desired. An ideal biomaterial surface with antibacterial activity can prevent the initial stages of infection such as bacterial adhesion and inhibit bacterial growth at later stages.

Therefore, the purpose of this study was to fabricate a novel implant surface that realizes longterm antibacterial effects for the prevention of lateonset infections. The development of a customized MAO treatment technique that enables the incorporation of multiple antibacterial elements into the resulting oxide layer on $\mathrm{Ti}$ was studied. In the primary phase of this study, a two-step MAO treatment was investigated for the fabrication of a specimen containing both $\mathrm{Ag}$ and $\mathrm{Zn}$ in its surface oxide layer. Surface analyses and metal-ion release tests were performed to investigate the presence of $\mathrm{Ag}$ and $\mathrm{Zn}$ in the oxide layer. The antibacterial properties of the specimens were also evaluated using gram-negative facultative anaerobic bacteria.

\section{MATERIALS AND METHODS}

\section{Specimen preparation}

Two types of specimen disks with diameters of 8 and $25 \mathrm{~mm}$ were fabricated by mechanically cutting rods of commercially pure grade $2 \mathrm{Ti}$. The $8 \mathrm{~mm}$ Ti disks were used for the surface characterization and the $25 \mathrm{~mm}$ Ti disks were used for the metal-ion release and the antibacterial property evaluations.

The surfaces of the disks were mechanically ground using \#150, \#320, \#600, and \#800 grid SiC abrasive papers. This was followed by ultrasonication using acetone and isopropanol. The disks were then kept in an auto-dry desiccator until further use. The Ti disk was fixed onto a polytetrafluoroethylene holder with an O-ring. The area in contact with the electrolyte was $39 \mathrm{~mm}^{2}$ (7.0 $\mathrm{mm}$ in diameter) or $398 \mathrm{~mm}^{2}(22.5 \mathrm{~mm}$ in diameter). Details of the working electrode are the same as described in a previous study ${ }^{36)}$. A type 304 stainless steel plate was used as the counter electrode. The base composition of the electrolyte for the MAO treatment was $100 \mathrm{mM}$ calcium glycerophosphate and $150 \mathrm{mM}$ calcium acetate.

In this study, either $0-10 \mathrm{mM}$ silver nitrate $\left(\mathrm{AgNO}_{3}\right)$ or $2 \mathrm{mM}$ zinc chloride $\left(\mathrm{ZnCl}_{2}\right)$ was added to the base electrolyte. After pouring the electrolyte into the electrochemical cell, both electrodes were connected to a DC power supply (PL-650-0.1, Matsusada Precision, Shiga, Japan), and a positive voltage with a constant current density of $251 \mathrm{Am}^{-2}$ was applied for $10 \mathrm{~min}$. Thus, a major part of the Ti disk was MAO-treated, with an annular untreated area of $0.5 \mathrm{~mm}$ from the edge.

The two-step MAO treatment was performed by following manner. In the first step, the MAO treatment was started in the first electrolyte until a voltage of $340 / 360 / 380 \mathrm{~V}$ was obtained. Then, the current application was stopped and the electrolyte was replaced immediately with the second electrolyte. Current was applied once again with an upper limit of $400 \mathrm{~V}$ for a total treatment time of $10 \mathrm{~min}$. The definition of specimen's name was "First electrolyte"/"Electrolyte replacing voltage"+"Second electrolyte"/"Final voltage" (For example, "2Zn/380V+10Ag/400V”). Surface characterization and metal-ion release/microbial measurements were performed on the MAO-treated area and the whole specimen area, respectively.

Surface characterization and metal-ion release evaluation A scanning electron microscope (SEM) with an energy dispersive X-ray spectrometer (EDS; S-3400NX, Hitachi High-Technologies, Tokyo, Japan) was used to observe the surface morphology and perform elemental analysis of each specimen. An inductively coupled plasma atomic emission spectrometer (ICP-AES; ICPS-7000 ver. 2, Shimadzu, Kyoto, Japan) was used to investigate the amounts of released $\mathrm{Ag}$ and $\mathrm{Zn}$ ions. The MAO-treated specimen in the electrolyte with/without $\mathrm{Ag}$ and $\mathrm{Zn}$ under various combination treatment conditions was incubated in $5 \mathrm{~mL}$ of physiological saline $(0.9 \% \mathrm{NaCl})$. They were sealed in a polyethylene container to allow the release of $\mathrm{Ag}$ and $\mathrm{Zn}$ ions from the surface of the specimen. These were maintained in a thermostatic chamber at $37^{\circ} \mathrm{C}$ under moderate shaking (80-100 rpm). 
Every seventh day, the pooled solution was transferred into fresh physiological saline. The concentrations of $\mathrm{Ag}$ and $\mathrm{Zn}$ ions in the tested solutions collected at the first (0-7 days), second (8-14 days), third (15-21 days), and fourth (22-28 days) periods were measured by ICPAES. After the evaluation of metal-ion release in the specimens that had been immersed in physiological saline for 28 days, the specimens were used as "aged specimen" to compare the antibacterial properties with those of the as-prepared fresh specimens.

\section{Evaluation of antibacterial properties}

The antibacterial property tests were conducted in accordance with domestic and international standard methods (JIS Z2801 and ISO 22196:2007). The proliferation of anaerobic gram-negative bacteria $(E$. coli, NBRC3972, NITE, Tokyo, Japan) on the specimens was evaluated. The suspension medium was prepared by five-hundred-fold dilution of the nutrient broth containing $3 \mathrm{gL}^{-1}$ meat extract, $10 \mathrm{gL}^{-1}$ peptone, and 5 $\mathrm{gL}^{-1}$ sodium chloride. The $\mathrm{pH}$ of the suspension medium was adjusted using sodium hydroxide or hydrochloric acid to be between 6.8 and 7.2. The bacteria were added to the suspension medium to obtain $3.1 \times 10^{6}$ colony forming units (CFU) $\mathrm{mL}^{-1}$. The bacterial suspension $(0.1$ $\mathrm{mL}$ ) was dropped onto a specimen and a cover film was placed immediately. The specimens and the cover films were incubated at $35^{\circ} \mathrm{C}$ for $24 \mathrm{~h}$. Thereafter, they were washed using $9.9 \mathrm{~mL}$ of sterile physiological saline. The CFU of the living bacteria dispersed into the saline was determined using the culture medium sheet for $E$. coli (JNC, Tokyo, Japan).

\section{RESULTS AND DISCUSSION}

Development of a two-step MAO treatment

To consider the multiple layers containing both $\mathrm{Ag}$ and $\mathrm{Zn}$ on $\mathrm{Ti}$, the problem of the upper limit of $\mathrm{AgNO}_{3}$ concentration in the electrolyte for MAO treatment should first be solved because it limits the amount of incorporated $\mathrm{Ag}$ in the resulting oxide layer. In our previous study ${ }^{29)}$, a porous oxide layer could not be formed using the electrolyte with $10 \mathrm{mM} \mathrm{AgNO}$ because the applied voltage during the treatment was inadequate. Figure 1 shows the change in voltage during the MAO treatment with various $\mathrm{AgNO}_{3}$ concentrations. When the MAO treatments were performed using electrolytes containing low to zero concentration of $2.5 \mathrm{mM} \mathrm{AgNO}_{3}$, the voltage continued to increase and finally reached a maximum value of $400 \mathrm{~V}$, which was set for this study. On the other hand, the voltage suddenly dropped during treatment in the case in which electrolytes with higher $\mathrm{AgNO}_{3}$ concentrations were used. In such cases, no porous oxide layer was formed on the Ti surface. It was considered that the electrical resistance of the resultant oxide layer reduced when the $\mathrm{Ag}$ concentration was too $\mathrm{high}^{29}$. Therefore, the growth of the oxide layer, which is a typical phenomenon in valve metals, was inhibited. It was found that the upper limit of $\mathrm{AgNO}_{3}$ concentration in the electrolyte was less than $5 \mathrm{mM}$ for the original

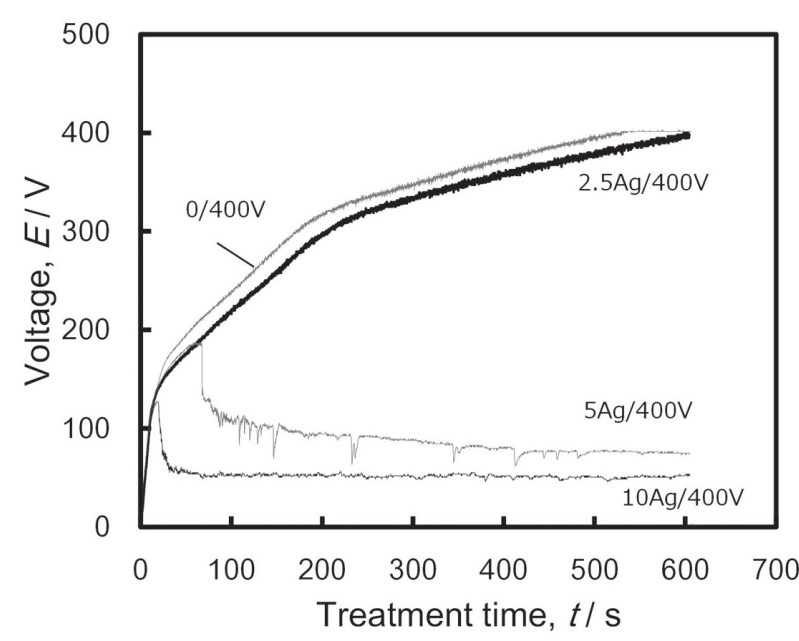

Fig. 1 Change in voltage during MAO treatment with various $\mathrm{AgNO}_{3}$ concentrations.

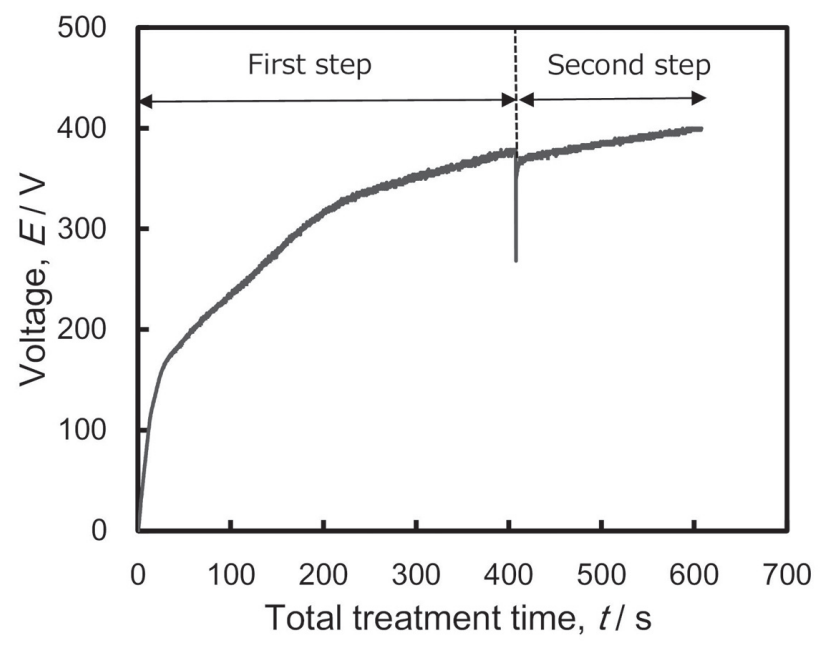

Fig. 2 Change in voltage during the two-step MAO treatment under the aforementioned conditions $(0 / 380 \mathrm{~V}+10 \mathrm{Ag} / 400 \mathrm{~V})$.

single-step MAO treatment condition.

Therefore, the two-step MAO treatment was considered to solve the aforementioned upper limit problem of the antibacterial source in the electrolyte. In the first step, the MAO treatment was started in the base composition electrolyte without $\mathrm{AgNO}_{3}$ until a voltage of $380 \mathrm{~V}(0 / 380 \mathrm{~V})$ was obtained. The current application was stopped, and the electrolyte was replaced immediately with the new electrolyte containing $10 \mathrm{~mA}$ of $\mathrm{AgNO}_{3}$. Current was applied once again with an upper limit of $400 \mathrm{~V}(10 \mathrm{Ag} / 400 \mathrm{~V})$ for a total treatment time of $10 \mathrm{~min}$. Figure 2 shows the change in the voltage during the two-step MAO treatment under the above conditions $(0 / 380 \mathrm{~V}+10 \mathrm{Ag} / 400 \mathrm{~V})$. The two-step MAO treatment finished without any voltage drop problem even though a high concentration of $\mathrm{Ag}$ ions was contained 
in the electrolyte for the second step. It was confirmed that when the oxide layer with high-enough electric resistance was properly formed in the first step, larger concentration of $\mathrm{Ag}$ ions in the second electrolyte and the newly-formed oxide layer did not affect the breakdown process during the treatment. In other words, the MAO treatment can be used with the condition of using higher Ag-ion concentration if the base oxide layer was formed in advance.

EDS measurements were performed to evaluate the amounts of $\mathrm{Ag}$ incorporated into the resulting oxide layers by single- and two-step MAO treatments under various conditions. The chemical compositions of the oxide layers were almost same irrelevant to the treatment conditions: Ti: 12 at\%, O: 67 at\%, C: 3 at\%, Ca: 9 at\%, and P: 9 at\%. However, slight amount of both $\mathrm{Ag}$ and $\mathrm{Zn}$ were detected from the specimens treated with the electrolytes containing these antibacterial elements. Figure 3 shows the relationship between the $\mathrm{AgNO}_{3}$ concentrations in the treatment electrolyte for the second step of treatment and the amount of $\mathrm{Ag}$ incorporated into the resulting oxide layers. The electrolyte replacement was performed at 340,360, and $380 \mathrm{~V}$. A higher electrolyte replacing voltage resulted in a shorter treatment time because the total treatment time was limited to $10 \mathrm{~min}$. From the results shown in Fig. 3, the amount of $\mathrm{Ag}$ incorporated in the oxide layer effectively increased with an increase in the concentration of $\mathrm{AgNO}_{3}$ in the second-step electrolyte. On the other hand, the replacing voltage had a relatively negligible effect on Ag incorporation. The amount of $\mathrm{Ag}$ incorporated into the oxide layer on the specimen $0 / 380 \mathrm{~V}+10 \mathrm{Ag} / 400 \mathrm{~V}$ was much higher than that of $2.5 \mathrm{Ag} / 400 \mathrm{~V}$, which is the best condition for single-step MAO treatment. Ag incorporation might have occurred mainly at the later stage of treatment with higher applied voltage. Thus, it was confirmed that the two-

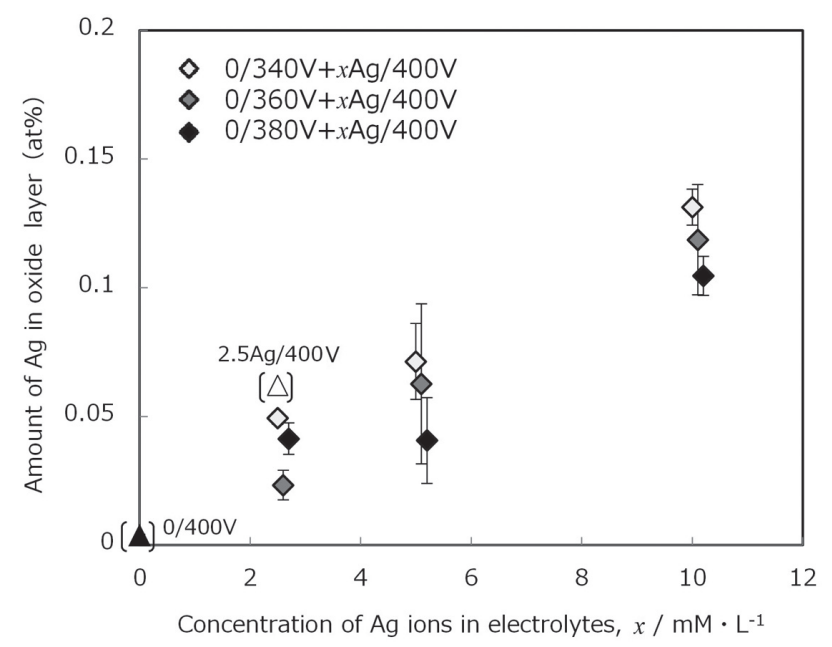

Fig. 3 Relationship between the $\mathrm{AgNO}_{3}$ concentrations in the treatment electrolyte for step two of the treatment and the amount of incorporated $\mathrm{Ag}$ into the resulting oxide layers. step MAO treatment is suitable to prepare specimens with higher concentration of $\mathrm{Ag}$.

From the experimental results of the fundamental two-step MAO treatment, we attempted to incorporate both $\mathrm{Zn}$ and $\mathrm{Ag}$ into the oxide layer on Ti. The electrolyte containing $2.0 \mathrm{mM} \mathrm{ZnCl} \mathrm{Zn}_{2}$ with basic components was used in the first step until $380 \mathrm{~V}$; then, it was replaced with an electrolyte containing $10 \mathrm{mM} \mathrm{AgNO}_{3}$ $(2 \mathrm{Zn} / 380 \mathrm{~V}+10 \mathrm{Ag} / 400 \mathrm{~V})$. The change in voltage during the treatment is shown in Fig. 4. The two-step MAO treatment using both $\mathrm{Zn}$ and $\mathrm{Ag}$ species was successful without any voltage drop problem. The amounts of $\mathrm{Ag}$ and $\mathrm{Zn}$ in the oxide layer were measured by EDS, and the experimental results are shown in Fig. 5. The Figure also shows experimental results of the reference specimens that were prepared by single-step MAO $(2 \mathrm{Zn} / 400 \mathrm{~V}$ and $2.5 \mathrm{Ag} / 400 \mathrm{~V})$ and two-step MAO with alternative antibacterial elements $(2 \mathrm{Zn} / 380 \mathrm{~V}+0 / 400 \mathrm{~V}$ and $0 / 380 \mathrm{~V}+10 \mathrm{Ag} / 400 \mathrm{~V})$. Both $\mathrm{Ag}$ and $\mathrm{Zn}$ were detected

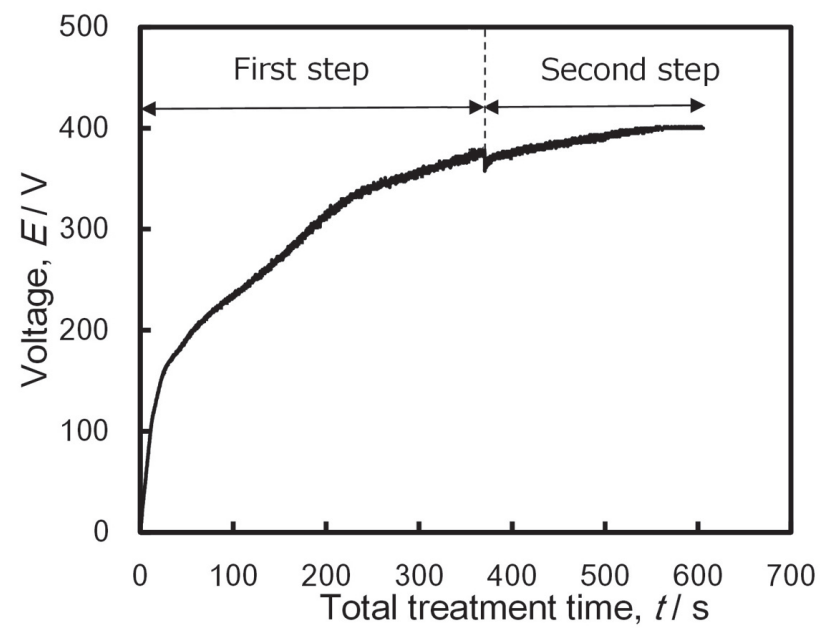

Fig. 4 Change in voltage during the two-step MAO treatment under the aforementioned conditions $(2 \mathrm{Zn} / 380 \mathrm{~V}+10 \mathrm{Ag} / 400 \mathrm{~V})$.

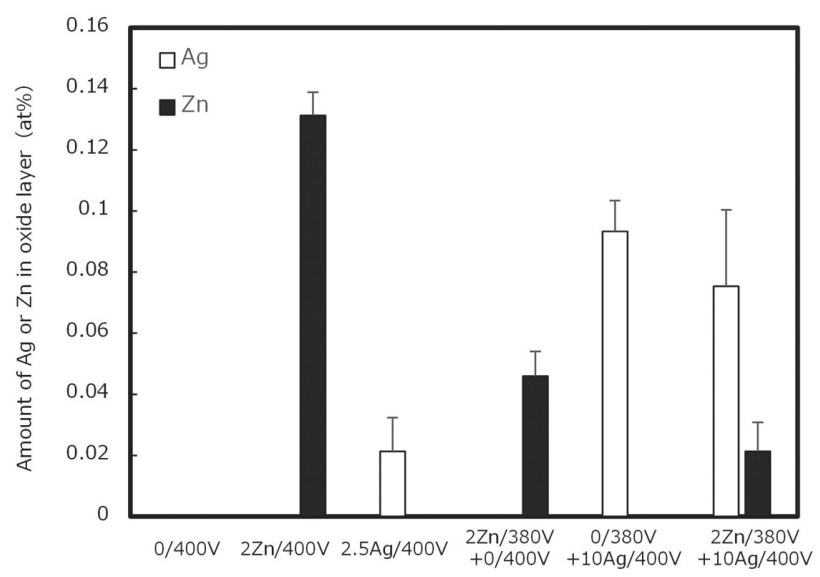

Fig. 5 The amounts of $\mathrm{Ag}$ and $\mathrm{Zn}$ in the oxide layer measured by EDS analysis. 
in $2 \mathrm{Zn} / 380 \mathrm{~V}+10 \mathrm{Ag} / 400 \mathrm{~V}$; therefore, it was confirmed that a novel oxide layer containing multiple antibacterial agents was realized by the proposed two-step MAO treatment. The amount of incorporated $\mathrm{Zn}$ decreased when the electrolyte was replaced with a zinc-free electrolyte at $380 \mathrm{~V}(2 \mathrm{Zn} / 400 \mathrm{~V}$ vs. $2 \mathrm{Zn} / 380 \mathrm{~V}+0 / 400 \mathrm{~V})$. The amount of incorporated $\mathrm{Zn}$ showed the same trend as that in the results of Ag discussed above. Furthermore, the amount of incorporated $\mathrm{Zn}$ also decreased when the electrolyte for the second step contained $10 \mathrm{mM}$ $\mathrm{AgNO}_{3}(2 \mathrm{Zn} / 380 \mathrm{~V}+0 / 400 \mathrm{~V}$ vs. $2 \mathrm{Zn} / 380 \mathrm{~V}+10 \mathrm{Ag} / 400 \mathrm{~V})$. In the same manner, the amount of incorporated $\mathrm{Ag}$ slightly decreased when the electrolyte for the first step contained $2 \mathrm{mM} \mathrm{ZnCl}_{2}(0 / 380 \mathrm{~V}+10 \mathrm{Ag} / 400 \mathrm{~V}$ vs. $2 \mathrm{Zn} / 380 \mathrm{~V}+10 \mathrm{Ag} / 400 \mathrm{~V})$. These results may be attributed to the conflicting effects of $\mathrm{Ag}$ and $\mathrm{Zn}$. However, in our previous study, the antibacterial effect of the specimen prepared by single-step MAO with $0.5 \mathrm{mM} \mathrm{ZnCl}_{2}(1 / 4$ concentration of $2 \mathrm{Zn} / 400 \mathrm{~V}$ in this study) was enhanced as well as that of the specimen with $2.5 \mathrm{mM} \mathrm{ZnCl}_{2}$ $(2.5 \mathrm{Zn} / 400 \mathrm{~V})$ after aging through a 28 days incubation in physiological saline ${ }^{32)}$. Therefore, the antibacterial effect of $\mathrm{Zn}$ in the $2 \mathrm{Zn} / 380 \mathrm{~V}+10 \mathrm{Ag} / 400 \mathrm{~V}$ specimen is also expected to be adequate.

Figure 6 shows the surface morphology of the MAOtreated specimen. There were many interconnected pores on the treated specimens. The number of pores and the pore size showed almost no apparent difference among the specimens under various treatment conditions. Therefore, it could be concluded that the effect of both the two-step method and the presence of $\mathrm{Ag}$ and/or $\mathrm{Zn}$ on the oxide layer morphology is insignificant.

Figure 7 shows the amount of $\mathrm{Ag}$ ions released from the oxide layer into the physiological saline, as determined by ICP-AES. The highest amount of Ag ions was released within the first 7 days, and thereafter it gradually diminished. The amount of Ag ions released

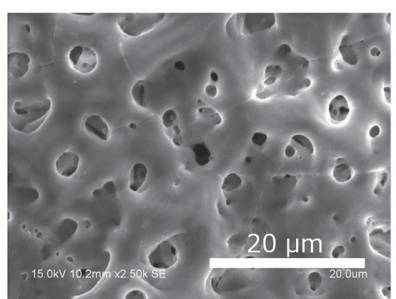

(a) $0 / 400 \mathrm{~V}$

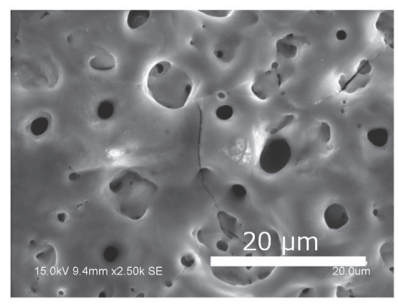

(c) $0 / 380 \mathrm{~V}+10 \mathrm{Ag} / 400 \mathrm{~V}$

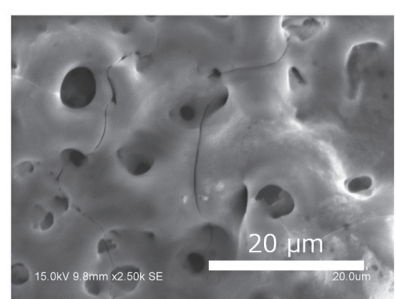

(b) $2 \mathrm{Zn} / 380 \mathrm{~V}+0 / 400 \mathrm{~V}$

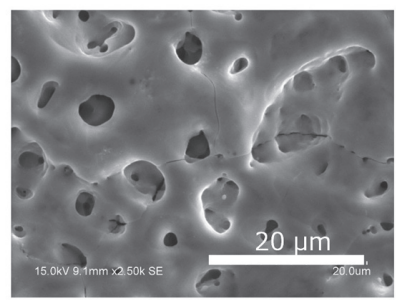

(d) $2 \mathrm{Zn} / 380 \mathrm{~V}+10 \mathrm{Ag} / 400 \mathrm{~V}$
Fig. 6 Surface morphology of the MAO-treated specimen by SEM. from the $2 \mathrm{Zn} / 380 \mathrm{~V}+10 \mathrm{Ag} / 400 \mathrm{~V}$ specimen was smaller than that from the $0 / 380 \mathrm{~V}+10 \mathrm{Ag} / 400 \mathrm{~V}$ specimen, in accordance with the Ag content (Fig. 5). Nevertheless, the release of $\mathrm{Ag}$ ions continued for at least 28 days. The volume of $\mathrm{Zn}$ ions released from the oxide layer in all tested specimens was below the ICP-AES detection limit. This may be due to the strong $\mathrm{Zn}$ ions adsorption effect followed by the simultaneous formation of zinc complexes on its surface ${ }^{37)}$. This also corresponds with the results from our previous study, which reported that $\mathrm{Zn}$ ions detected by ICP-AES from Zn-incorporated MAO specimens were vanishingly small, even though they showed significant antibacterial effects against $E$. coli $i^{32)}$

Therefore, the antibacterial properties of MAOtreated specimens containing both $\mathrm{Ag}$ and $\mathrm{Zn}$ were evaluated using E. coli (Fig. 8). E. coli could survive on the surface of the reference specimens untreated $\mathrm{Ti}$

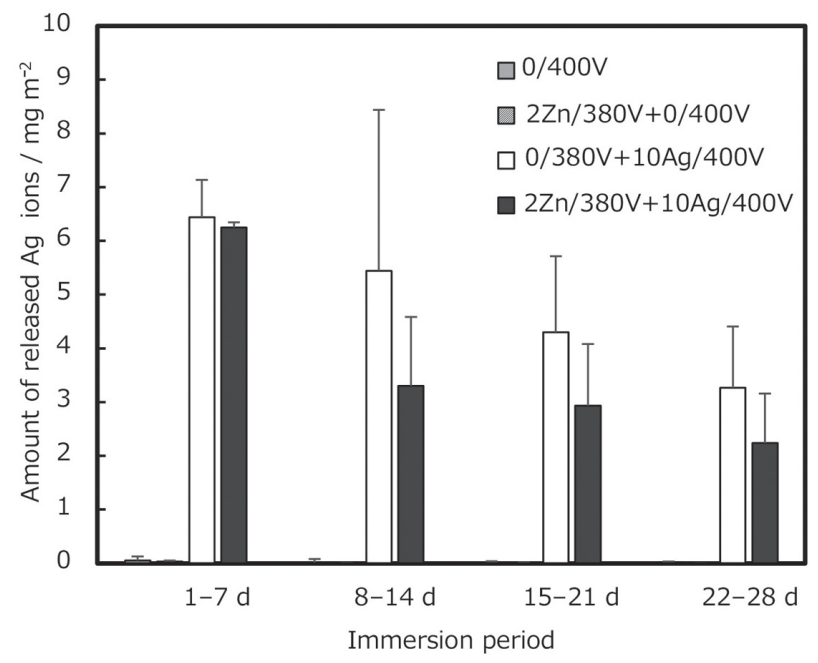

Fig. 7 The amount of $\mathrm{Ag}$ ions released from the oxide layer into physiological saline.

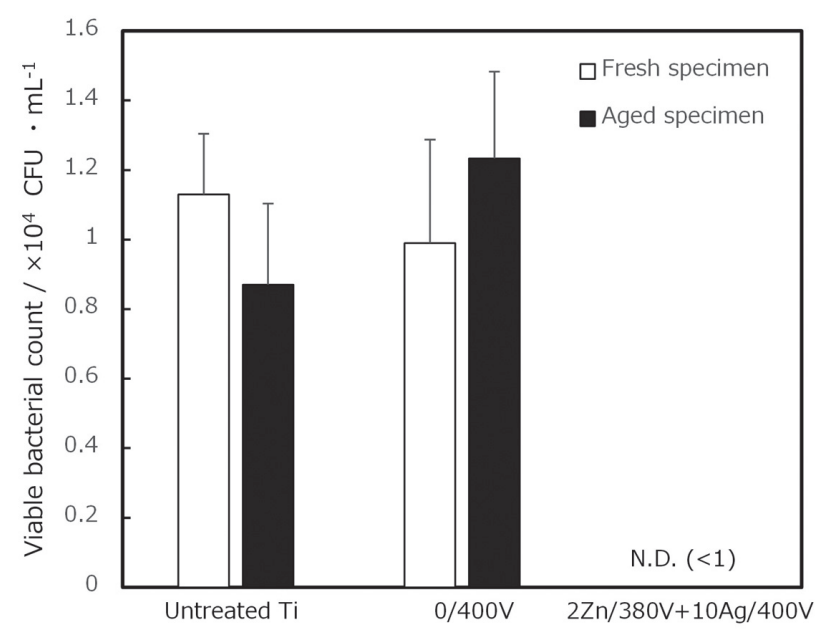

Fig. 8 Antibacterial property of MAO-treated specimen containing both $\mathrm{Ag}$ and $\mathrm{Zn}$. 
and MAO-treated Ti without antibacterial elements. In contrast, there was no bacterial colony $\left(<1 \mathrm{CFUmL}^{-1}\right)$ on the tested nutrient agar plates after incubation for $24 \mathrm{~h}$. Thus, it was found that $E$. coli was completely killed within $24 \mathrm{~h}$ on the specimen containing both $\mathrm{Zn}$ and $\mathrm{Ag}$. This strong antibacterial property against freshly prepared specimens of $E$. coli might be mainly derived from $\mathrm{Ag}$ ions released from the porous oxide layer, as shown in Fig. 7. However, the amount of Agion released continued to decrease during the period of immersion in physiological saline, and it dropped by about one-third after 28 days. It was expected that the antibacterial property of the MAO-treated specimen would weaken because of the diminishing Ag-ion release in accordance with the immersion period, simulating practical usage. However, the experimental results using aged $2 \mathrm{Zn} / 380 \mathrm{~V}+10 \mathrm{Ag} / 400 \mathrm{~V}$ specimen (after 28 days immersion in physiological saline at $37^{\circ} \mathrm{C}$ ) also results in no bacteria. It could be considered that the formation and the maturation of $\mathrm{Zn}$ products ${ }^{32}$ on the specimen surface occurred gradually during the immersion period. Therefore, this prolonged antibacterial efficacy could be attributed to the presence of $\mathrm{Zn}$. It was confirmed that the excellent antibacterial property of Ti could be maintained even after a 28 days-aging period by the proposed two-step MAO treatment.

Some limitations exist in this study. First, the efficacy of $\mathrm{Zn}$ after an incubation period of 28 days was not fully distinguished from that of Ag. We plan to optimize the treatment conditions, such as using an increased aging period to discern the effort of $\mathrm{Zn}$, and adjusting the amount of incorporated $\mathrm{Ag}$ and $\mathrm{Zn}$ because excess Ag-ion release can cause a cytotoxic effect ${ }^{38-43}$. Realizing both antibacterial and hard-tissue compatibility is the ideal goal of this study ${ }^{29}$. The second limitation is the effectiveness of various bacterial species. $E$. coli is one of the standard testing bacteria; however, the effect of $\mathrm{Ag}$ and $\mathrm{Zn}$ on other bacteria is still unknown, even though Ag shows a broad antibacterial spectrum ${ }^{13-15,44-46)}$. Gram-positive facultative anaerobic bacteria (such as $S$. aureus) and primal bacteria that play important roles in biofilm formation in practical environments should be investigated in more detail.

\section{CONCLUSION}

Both $\mathrm{Ag}$ and $\mathrm{Zn}$ were successfully incorporated on the Ti surface using the proposed two-step MAO treatment. Moreover, a higher concentration of $\mathrm{Ag}$ could be incorporated by the two-step MAO than that by the traditional single-step MAO. E. coli was effectively killed on the MAO-treated specimen containing both $\mathrm{Ag}$ and $\mathrm{Zn}$. Excellent antibacterial property was sustained even after 28 days of immersion in physiological saline simulating the living environment. Optimization of the treatment conditions for incorporation of $\mathrm{Ag}$ and $\mathrm{Zn}$ can realize desirable bactericidal properties for a long time after implant surgery.

\section{ACKNOWLEDGMENTS}

This work was supported by a Grant-in-Aid for JSPS Research Fellow JP201940065. Part of this study was supported by the Research Center for Biomedical Engineering.

\section{REFERENCES}

1) Zubery $\mathrm{Y}$, Bichacho $\mathrm{N}$, Moses $\mathrm{O}$, Tal $\mathrm{H}$. Immediate loading of modular transitional implants: a histologic and histomorphometric study in dogs. Int $\mathrm{J}$ Periodontics Restorative Dent 1999; 19: 343-353.

2) Hui E, Chow J, Li D, Liu J, Wat P, Law H. Immediate provisional for single-tooth implant replacement with Brånemark system: Preliminary report. Clin Implant Dent Relat Res 2001; 3: 79-86.

3) Cochran DL, Buser D, Ten Bruggenkate CM, Weingart D, Taylor TM, Bernard JP, et al. The use of reduced healing times on ITI $^{\circledR}$ implants with a sandblasted and acid-etched (SLA) surface: Early results from clinical trials on ITI ${ }^{\circledR}$ SLA implants. Clin Oral Implants Res 2002; 13: 144-153.

4) Lorenzoni M, Pertl C, Zhang K, Wimmer G, Wegscheider WA. Immediate loading of single-tooth implants in the anterior maxilla. Preliminary results after one year. Clin Oral Implants Res 2003; 14: 180-187.

5) Paquette DW, Brodala N, Williams RC. Risk factors for endosseous dental implant failure. Dent Clin North Am 2006; 50: 361-374.

6) Dibart S, Warbington M, Su MF, Skobe Z. In vitro evaluation of the implant-abutment bacterial seal: The locking taper system. Int J Oral Maxillofac Implants 2005; 20: 732-737.

7) Glauser R, Schupbach P, Gottlow J, Hammerle CHF. Periimplant soft tissue barrier at experimental one-piece mini-implants with different surface topography in humans: A light-microscopic overview and histometric analysis. Clin Implant Dent Relat Res 2005; 7: s44-51.

8) Tesmer M, Wallet S, Koutouzis T, Lundgren T. Bacterial colonization of the dental implant fixture-abutment interface: An in vitro study. J Periodontol 2009; 80: 1991-1997.

9) MacKintosh EE, Patel JD, Marchant RE, Anderson JM. Effects of biomaterial surface chemistry on the adhesion and biofilm formation of Staphylococcus epidermidis in vitro. $\mathrm{J}$ Biomed Mater Res A 2006; 78: 836-842.

10) Ono M, Nikaido T, Iked M, Imai S, Hanada N, Tagami J, et al. Surface properties of resin composite materials relative to biofilm formation. Dent Mater J; 26: 613-622.

11) Meredith DO, Eschbach L, Wood MA, Riehle MO, Curtis ASG, Richards RG. Human fibroblast reactions to standard and electropolished titanium and Ti-6Al-7Nb, and electropolished stainless steel. J Biomed Mater Res A 2005; 75: 541-555

12) Koerner RJ, Butterworth LA, Mayer I V, Dasbach R, Busscher HJ. Bacterial adhesion to titanium-oxy-nitride (TiNOX) coatings with different resistivities: A novel approach for the development of biomaterials. Biomaterials 2002; 23: 28352840.

13) Simonetti N, Simonetti G, Bougnol F, Scalzo M. Electrochemical Ag+ for preservative use. Appl Environ Microbiol 1992; 58: 3834-3836.

14) Wassall MA, Santin M, Isalberti C, Cannas M, Denyer SP. Adhesion of bacteria to stainless steel and silver-coated orthopedic external fixation pins. J Biomed Mater Res 1997; 36: 325-330.

15) Massè A, Bruno A, Bosetti M, Biasibetti A, Cannas M, Gallinaro P. Prevention of pin track infection in external fixation with silver coated pins: Clinical and microbiological results. J Biomed Mater Res 2000; 53: 600-604.

16) Samani S, Hossainalipour SM, Tamizifar M, Rezaie HR. In 
vitro antibacterial evaluation of sol-gel-derived Zn-, Ag-, and $(\mathrm{Zn}+\mathrm{Ag})$-doped hydroxyapatite coatings against methicillinresistant Staphylococcus aureus. J Biomed Mater Res A 2013; 101: 222-230.

17) Jin G, Qin H, Cao H, Qian S, Zhao Y, Peng X, et al. Synergistic effects of dual $\mathrm{Zn} / \mathrm{Ag}$ ion implantation in osteogenic activity and antibacterial ability of titanium. Biomaterials 2014; 35: 7699-7713.

18) Appierot G, Lipovsky A, Dror R, Perkas N, Nitzan Y, Lubart $\mathrm{R}$, et al. Enhanced antibacterial actiwity of nanocrystalline $\mathrm{ZnO}$ due to increased ROS-mediated cell injury. Adv Funct Mater 2009; 19: 842-852.

19) Storrie H, Stupp SI. Cellular response to zinc-containing organoapatite: An in vitro study of proliferation, alkaline phosphatase activity and biomineralization. Biomaterials 2005; 26: 5492-5499.

20) Jones N, Ray B, Ranjit KT, Manna AC. Antibacterial activity of $\mathrm{ZnO}$ nanoparticle suspensions on a broad spectrum of microorganisms. FEMS Microbiol Lett 2008; 279: 71-76.

21) Dastjerdi R, Montazer M. A review on the application of inorganic nano-structured materials in the modification of textiles: Focus on anti-microbial properties. Colloids Surf B Biointerfaces 2010; 79: 5-18.

22) Raghupathi KR, Koodali RT, Manna AC. Size-dependent bacterial growth inhibition and mechanism of antibacterial activity of zinc oxide nanoparticles. Langmuir 2011; 27: 40204028.

23) Suh JY, Jang BC, Zhu X, Ong JL, Kim K. Effect of hydrothermally treated anodic oxide films on osteoblast attachment and proliferation. Biomaterials 2003; 24: 347355.

24) Son WW, Zhu X, Shin HI, Ong JL, Kim KH. In vivo histological response to anodized and anodized/hydrothermally treated titanium implants. J Biomed Mater Res B Appl Biomater 2003; 66: 520-525

25) Kim DY, Kim M, Kim HE, Koh YH, Kim HW, Jang JH. Formation of hydroxyapatite within porous $\mathrm{TiO} 2$ layer by micro-arc oxidation coupled with electrophoretic deposition. Acta Biomater 2009; 5: 2196-2205.

26) Li Y, Lee IS, Cui FZ, Choi SH. The biocompatibility of nanostructured calcium phosphate coated on micro-arc oxidized titanium. Biomaterial. 2008; 29: 2025-2032.

27) Tsutsumi Y, Niinomi M, Nakai M, Tsutsumi H, Doi H, Nomura $\mathrm{N}$, et al. Micro-arc oxidation treatment to improve the hard-tissue compatibility of Ti-29Nb-13Ta-4.6Zr alloy. Appl Surf Sci 2012; 262: 34-38.

28) Ha JY, Tsutsumi Y, Doi H, Nomura N, Kim KH, Hanawa T. Enhancement of calcium phosphate formation on zirconium by micro-arc oxidation and chemical treatments. Surf Coatings Technol 2011; 205: 4948-4955.

29) Shimabukuro M, Tsutsumi Y, Yamada R, Ashida M, Chen $\mathrm{P}$, Doi $\mathrm{H}$, et al. Investigation of realizing both antibacterial property and osteogenic cell compatibility on titanium surface by simple electrochemical treatment. ACS Biomater Sci Eng 2019; 5: 5623-5630.

30) Shimabukuro M, Tsutsumi Y, Nozaki K, Chen P, Yamada R, Ashida M, et al. Investigation of antibacterial effect of copper introduced titanium surface by electrochemical treatment against facultative anaerobic bacteria. Dent Mater J 2020;
39: 639-647.

31) Shimabukuro M, Manaka T, Tsutsumi Y, Nozaki K, Chen P, Ashida $\mathrm{M}$, et al. Corrosion behavior and bacterial viability on different surface states of copper. Mater Trans 2020; 61: 1143-1148.

32) Shimabukuro M, Tsutsumi Y, Nozaki K, Chen P, Yamada R, Ashida M, et al. Chemical and biological roles of zinc in a porous titanium dioxide layer formed by micro-arc oxidation. Coatings 2019; 9: 705.

33) Coventry MB. Treatment of infections occurring in total hip surgery. Orthop Clin North Am 1975; 6: 991-1003.

34) Rees RT, Mont MA. Infections associated with dental procedures in total hip arthroplasty (multiple letter) [5]. Vol. 82, Journal of Bone and Joint Surgery -Series B. The British Editorial Society of Bone and Joint Surgery; 2000. p. 307.

35) Rubin R, Salvati EA, Lewis R. Infected total hip replacement after dental procedures. Oral Surg Oral Med Oral Pathol 1976; 41: 18-23.

36) Tanaka Y, Kobayashi E, Hiromoto S, Asami K, Imai H, Hanawa T. Calcium phosphate formation on titanium by lowvoltage electrolytic treatments. J Mater Sci Mater Med 2007; 18: 797-806.

37) Odnevall Wallinder I, Leygraf C. A critical review on corrosion and runoff from zinc and zinc-based alloys in atmospheric environments. Corrosion 2017; 73: 1016-1077.

38) Poon VKM, Burd A. In vitro cytotoxity of silver: Implication for clinical wound care. Burns 2004; 30: 140-147.

39) Wataha JC, Lockwood PE, Schedle A. Effect of silver, copper, mercury, and nickel ions on cellular proliferation during extended, low-dose exposures. J Biomed Mater Res 2000; 52: 360-364.

40) Yamamoto A, Honma R, Sumita M. Cytotoxicity evaluation of 43 metal salts using murine fibroblasts and osteoblastic cells. J Biomed Mater Res 1998; 39: 331-340.

41) AshaRani PV, Mun GLK, Hande MP, Valiyaveettil S. Cytotoxicity and genotoxicity of silver nanoparticles in human cells. ACS Nano 2009; 3: 279-290.

42) Rosário F, Hoet P, Santos C, Oliveira H. Death and cell cycle progression are differently conditioned by the AgNP size in osteoblast-like cells. Toxicology 2016; 368-369: 103-115.

43) Contreras RG, Vilchis JRS, Sakagami H, Nakamura Y, Nakamura Y, Hibino Y, et al. Type of cell death induced by seven metals in cultured mouse osteoblastic cells. In Vivo (Brooklyn) 2010; 24: 507-512.

44) Shao W, Liu X, Min H, Dong G, Feng Q, Zuo S. Preparation, characterization, and antibacterial activity of silver nanoparticle-decorated graphene oxide nanocomposite. ACS Appl Mater Interfaces 2015; 7: 6966-6973.

45) Jia Z, Xiu P, Li M, Xu X, Shi Y, Cheng Y, et al. Bioinspired anchoring AgNPs onto micro-nanoporous $\mathrm{TiO} 2$ orthopedic coatings: Trap-killing of bacteria, surface-regulated osteoblast functions and host responses. Biomaterials 2016; 75: 203222.

46) De Faria AF, Perreault F, Shaulsky E, Arias Chavez LH, Elimelech M. Antimicrobial electrospun biopolymer nanofiber mats functionalized with graphene oxide-silver nanocomposites. ACS Appl Mater Interfaces 2015; 7: 1275112759 . 